\title{
アモルファス三酸化モリブデン薄膜の イオンレジスト効果*
}

\author{
池津 勇一**. 越田 信義**
}

(昭和 60 年 9 月 3 日受理)

\section{Properties of Amorphous $\mathrm{MoO}_{3}$ Film as an Ion Resist Yuichi IKETSU and Nobuyoshi KOSHIDA}

(Department of Electronic Engineering, Faculty of Technology, Tokyo University of Agriculture and Technology, Koganei, Tokyo 184, Japan)

(Received September 3, 1985)

\begin{abstract}
Ion-beam modification of thin amorphous films of molybdenum trioxide $\left(\mathrm{a}-\mathrm{MoO}_{3}\right)$ was studied using thermionic sodium ions with an accelerating voltage of $4-12 \mathrm{kV}$. The films become abruptly insoluble in alkaline solutions at ion doses beyond a threshold value $D_{\mathrm{th}}$. The a- $\mathrm{MoO}_{3}$ film is potentially useful as a negative-type inorganic ion resist with extremely high contrast. From the analysis of the voltage dependence of $D_{\mathrm{th}}$, it is suggested that the resistive property is a result of the insulator-metal transition of sodium molybdenum bronze $\left(\mathrm{Na}_{x} \mathrm{MoO}_{3}\right)$ produced by ion implantation. This hypothesis is also supported by a significant decrease in the sheet resistance of the film with increasing ion dose.
\end{abstract}

\section{1. まえがき}

半導体微細加工プロセスにおいて, リソグラフィーは 最も重要な技術の一つである. 現在はホトリソグラフィ 一が最も多く使われているが, 波動性の強い光では，実 現できるパターンの解像度が用いる光の波長に制限され てしまうという問題がある。そこでVLSI などの集積度 の増大に対応するため, X 線や粒子性の強い電子ビー ムまたはイオンビームによる露光法が開発されてきてい る. また, これにともなって, 高感度, 高解像度のレジ スト材料の開発も必要となっている。

本研究でとりあげるイオンビームは, 電子ビームと比 較して固体中での散乱が少ないため, 優れた解像度が期 待できる. また, 電界および磁界によりビームの集束, 偏向, 走查などの制御が比較的容易にでき, レジスト上 に直接パターンを描画できる可能性もある ${ }^{11}$. 一方, レ ジスト材料としては現在, 有機レジストが一般に用いら れているが, 解像度の点では巨大分子構造をもたない無

* 昭和60年 4 月 1 日 第32回応用物理学関保連合講演会で発表

** 東京農工大学工学部電子工学科（東京都小金井市中町2-24-16）
機レジストが本質的に有利と思われる.

われわれは先に,アモルファス三酸化タングステン $\left(\mathrm{a}-\mathrm{WO}_{3}\right)$ 薄膜が非常にコントラストの高いネガ形のイ オンレジスト効果を示すことを報告した ${ }^{2)}$. イオン照射 後の光学的特性などから判断して,レジスト効果の原因 はイオン注入によるタングステンブロンズの生成にある という可能性が高い3). したがって，この効果はブロン ズを作る他の遷移金属酸化物共通の特性と思われる。そ こでここでは，アモルファス三酸化モリブデン（a$\left.\mathrm{MoO}_{3}\right)$ 薄膜をとりあげ, イオンビーム露光特性を測定 した. その結果, $\mathrm{a}-\mathrm{WO}_{3}$ 薄膜と同様のレジスト効果が 認められた。 また，レジス卜感度特性および電気的特性 などから，レジスト効果発現の機構について先の予測を 支持する若干の知見が得られたので, それらの結果を報 告する.

\section{2. 実 験}

$\mathrm{MoO}_{3}$ 薄膜は純度 $99.99 \%$ の $\mathrm{MoO}_{3}$ 粉末を W ボートに のせ, 抵抗加熱蒸着により透明電極 $\left(\mathrm{In}_{2} \mathrm{O}_{3}\right)$ をコート したガラス基板上に形成する. 蒸着時の真空度は $10^{-4}$ 


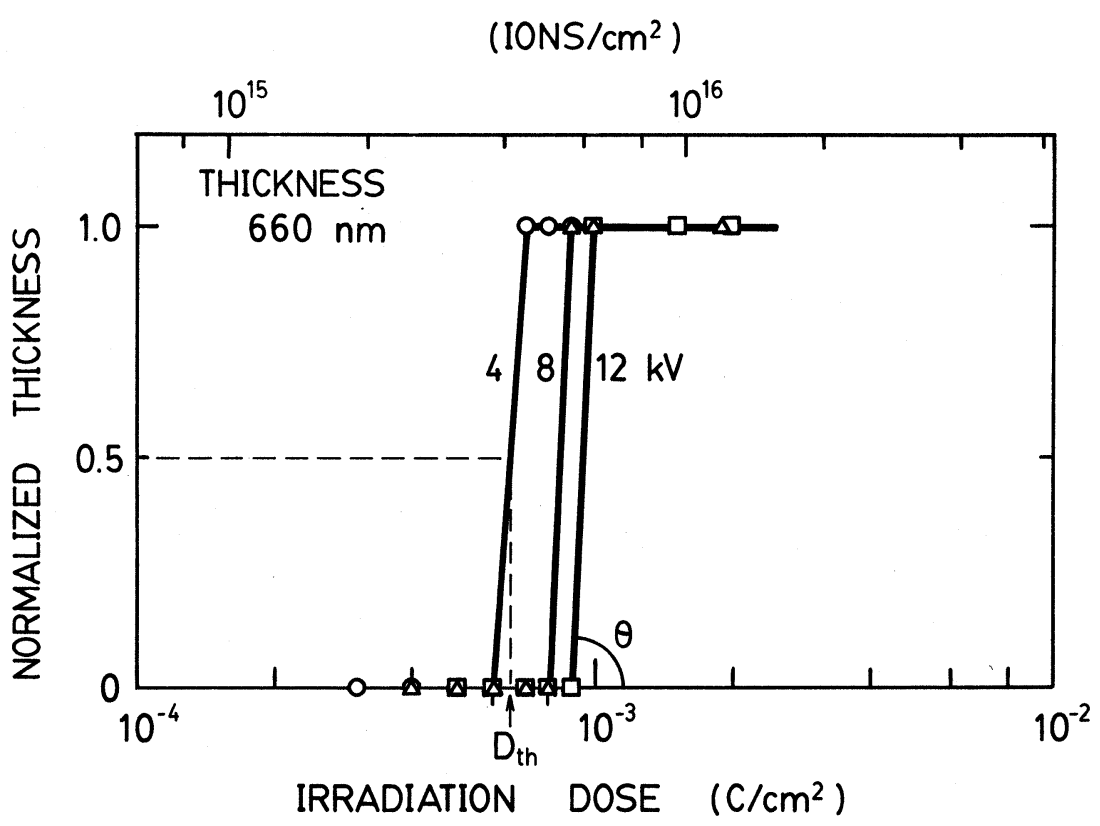

Fig. 1 Contrast curves of a-MoO 3 film exposed to different doses of sodium ions. Threshold dose $D_{\text {th }}$ is defined as an ion dose which results in $50 \%$ thickness remaining.

$\mathrm{Pa}$ 程度，基板温度は $100^{\circ} \mathrm{C}$ である。膜厚は $150 \sim 660$ $\mathrm{nm}$ とした。作成した $\mathrm{MoO}_{3}$ 薄膜は $\mathrm{X}$ 線回折によりア モルファス状態であることが確認されている，照射する イオンは $\mathrm{Na}^{+}$ビームで，線径 $0.08 \mathrm{~mm}$ の白金メッシュ とケイ酸ナトリウム $\left(\mathrm{Na}_{2} \mathrm{O} \cdot 2 \mathrm{SiO}_{2}\right)$ からなる直熱型の 熱イオンエミッタから放出される。このイオン源は使用 前に $10^{-4} \mathrm{~Pa}$ 程度の真空中で充分エージングする．放出 されたイオンは二段階で加速・集束され，偏向・走查系 を経てターゲットに達する，最終的なビーム径は $1 \mathrm{~mm}$ 以下，電流密度は $1 \sim 5 \mu \mathrm{A} / \mathrm{cm}^{2}$ である. 二次元的な偏向 ・走査により，同一ターゲット上の数カ所にイオンを照 射した。

$\mathrm{a}^{-} \mathrm{MoO}_{3}$ 薄膜への $\mathrm{Na}^{+}$の照射は $10^{-4} \mathrm{~Pa}$ 以下の真空 中で加速電圧 4 $12 \mathrm{kV}$ でおこなう。まず, $\mathrm{a}-\mathrm{MoO}_{3}$ 薄 膜のイオンビームによるレジスト効果を調べるため, イ オン照射後の $\mathrm{a}-\mathrm{MoO}_{3}$ 薄膜を $0.01 \sim 0.04 \mathrm{~N}$ の $\mathrm{NaOH}$ 水 溶液で化学エッチングし，イオンドースによるエッチン グ特性の変化を測定した，蒸着したままの $\mathrm{a}-\mathrm{MoO}_{3}$ 薄 膜のエッチング速度は 100 $200 \mathrm{~nm} / \mathrm{min}$ であった。 た, イオン照射部の $\mathrm{a}-\mathrm{MoO}_{3}$ 薄膜の室温での表面シー 卜抵抗を四端子法により測定し，イオンドースによる変 化も調べた。そのさい，電極には $\mathrm{Au}$ の蒸着膜を用い た.

\section{3. 結果と検討}

\section{1 露光特性}

Fig. 1 は $\mathrm{Na}^{+}$ビーム照射後の膜厚 $660 \mathrm{~nm}$ の $\mathrm{a}^{-}$ $\mathrm{MoO}_{3}$ 薄膜の $\mathrm{NaOH}$ 溶液によるエッチング特性をイオ ンドースに対して示したもので, 縦軸の原点は $\mathrm{a}^{-}$ $\mathrm{MoO}_{3}$ 薄膜が $\mathrm{NaOH}$ 溶液に完全に溶解したこと，1.0は 現像前の膜厚のまま溶けずに残ったことを意味する。こ の特性から $\mathrm{a}-\mathrm{MoO}_{3}$ 薄膜はイオンドースがある臨界值 を越えた所で急に $\mathrm{NaOH}$ 溶液に不溶性となり，ネガ形 のレジスト効果を示すことがわかる. 図中に示した $\theta$ か らコントラスト $\gamma(=\tan \theta)$ を求めると $8 \sim 10$ となり, 従来のネガ形有機イオンレジスト $(\gamma \simeq 1 \sim 2)^{4)}$ と比べる と，著しく高い値を示した．図の縦軸すなわち規格化膜 厚が 0.5 となる時のイオンドースを $D_{\mathrm{th}}$ とすると，これ は $\mathrm{a}-\mathrm{MoO}_{3}$ 薄膜のレジストとしての感度の目安となる. この $D_{\mathrm{th}}$ はイオン加速電圧 $V$ の上昇とともに若干増加す る. 膜厚 $660 \mathrm{~nm}$ 抢よび $200 \mathrm{~nm}$ の $\mathrm{a}-\mathrm{MoO}_{3}$ 薄膜の $D_{\mathrm{th}}$ の $V$ 依存性を Fig. 2 亿示す。本実験で用いた加速電圧 でのイオンによる改質は表面層に限定されたものである ことから，本来， $D_{\mathrm{th}}$ 特性は膜厚に依存しないはずであ る. しかし, 実際には膜厚が増すとアンダーエッチング の影響が現われやすくなり，見かけ上 $D_{\mathrm{th}}$ が大きくなる という結果となっている.この傾向は $\mathrm{a}-\mathrm{WO}_{3}$ において もみられた ${ }^{21}$. 


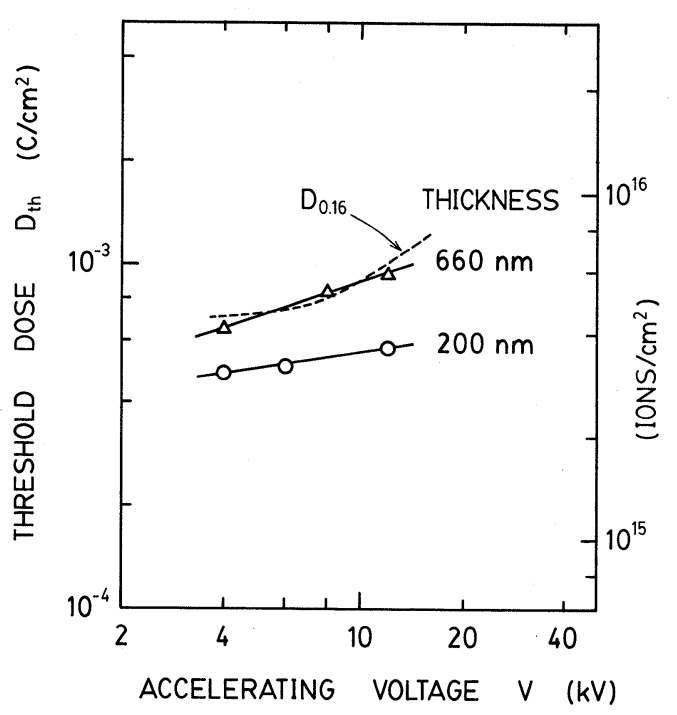

Fig. 2 Threshold dose $D_{\text {th }}$ as a function of accelerating voltage of ions. The voltage dependence of the dose, $D_{0.16}$, required to obtain a sodium composition at the surface of 0.16 is also shown by the dashed curve.

ところで， $\mathrm{a}-\mathrm{MoO}_{3}$ 薄膜に入射した $\mathrm{Na}$ は原子核や価 電子との相互作用によりしだいにそのエネルギーを失い, $\mathrm{a}-\mathrm{MoO}_{3}$ 薄膜中にある分布をむって停止する.この時, 基板がアモルファスであるので, 薄膜表面から $\mathrm{Na}$ が停 止した位置までの距離を入射方向へ投影した長さ（投影 飛程）の分布は正規分布で近似できる.イオンの平均投 影飛程 $R_{\mathrm{p}}$ および標準偏差 $\Delta R_{\mathrm{p}}$ の一般的な定式化は Lindhard $ら^{5)}$ によって報告されている. Dearnaley ら ${ }^{6)}$ はこ の LSS 理論に基づき，イオン加速電圧に対する $R_{\mathrm{p}}$, $\Delta R_{\mathrm{p}}$ の数值データをイオン種とターゲットのいろいろな 組み合せに適用可能な形で与えている，われわれはこの 数值データをもとに, $\mathrm{Na}^{+} を \mathrm{MoO}_{3}$ に照射した場合の $R_{\mathrm{p}}$ および $\Delta R_{\mathrm{p}}$ の $V$ 依存性を求めた。 その結果が Fig. 3 である．Vが増加すると $R_{\mathrm{p}}$ も増加するので, ドースが 一定な $5 \mathrm{a}-\mathrm{MoO}_{3}$ 薄膜表面の $\mathrm{Na}$ の濃度は減少する. $\mathrm{NaOH}$ 溶液に対する溶解性の変化が $\mathrm{a}-\mathrm{MoO}_{3}$ 薄膜表面 での $\mathrm{Na}$ 濃度の増加にともなう改質の結果と考えるなら ば，これを達成するためには $V$ の増加とともにより多 くの Na ドースが必要となり, Fig. 2 の傾向が説明でき る.レジスト効果の原因が単なるエネルギーデポジショ ンによる構造変化とすると, Fig. 3 における $R_{\mathrm{p}}$ の $V$ 依 存性（実験の電圧範囲では $R_{\mathrm{p}} \propto V^{n}$ で $n<1 ）$ からみて, $D_{\mathrm{th}}$ は $V$ の上昇に対して減少傾向を示すはずである.

\section{2 電気的特性}

Fig. 4 は膜厚 $150 \mathrm{~nm}$ の $-\mathrm{MoO}_{3}$ 薄膜に加速電圧 12

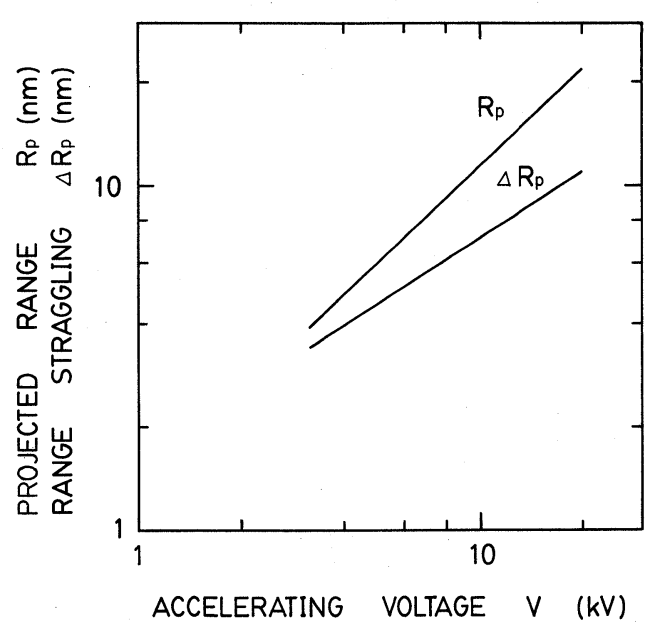

Fig. 3 Projected range $R_{\mathrm{p}}$ and its straggling $\Delta R_{\mathrm{p}}$ for sodium ions in $\mathrm{MoO}_{3}$ versus accelerating voltage.

$\left(\right.$ IONS $\left./ \mathrm{cm}^{2}\right)$

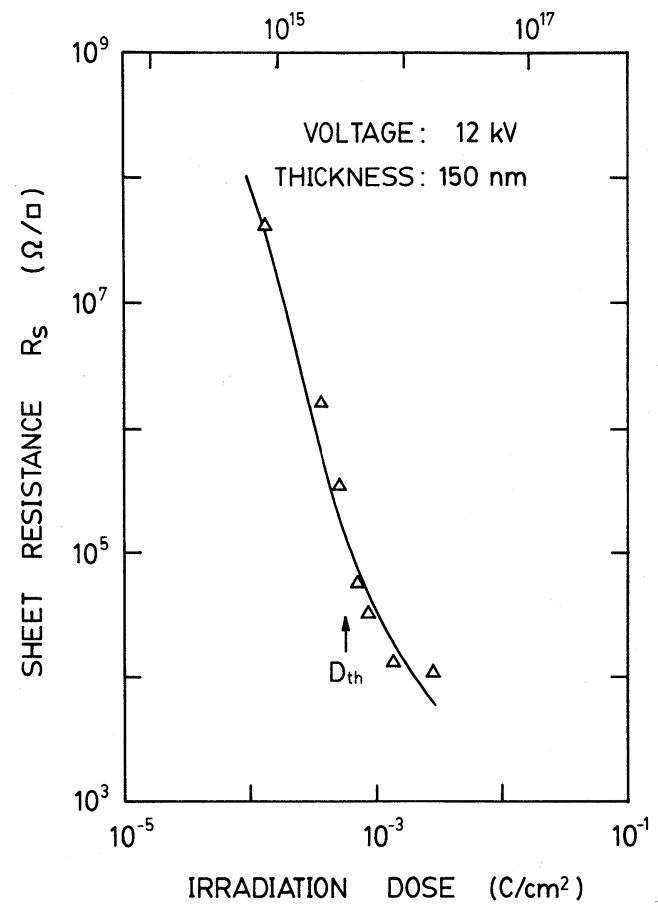

Fig. 4 Sheet resistance $R_{\mathrm{s}}$ of a-MoO $\mathrm{M}_{3}$ film as a function of ion dose. The threshold dose is also shown by the arrow.

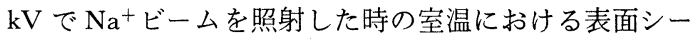
ト抵抗 $R_{\mathrm{s}}$ をイオンドースに対してプロットしたもので ある. $R_{\mathrm{s}}$ は $D_{\mathrm{th}}$ 付近でほぼ 4 桁にわたって急激な減少を 示している. イオンの投影飛程が膜厚の $5 \sim 6 \%$ しか 


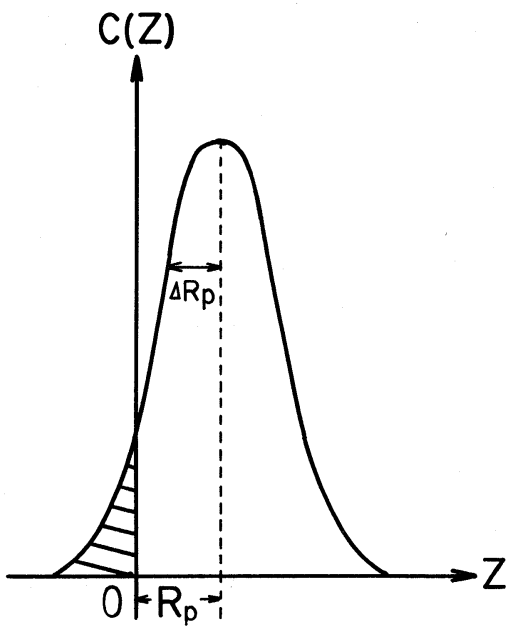

SURFACE

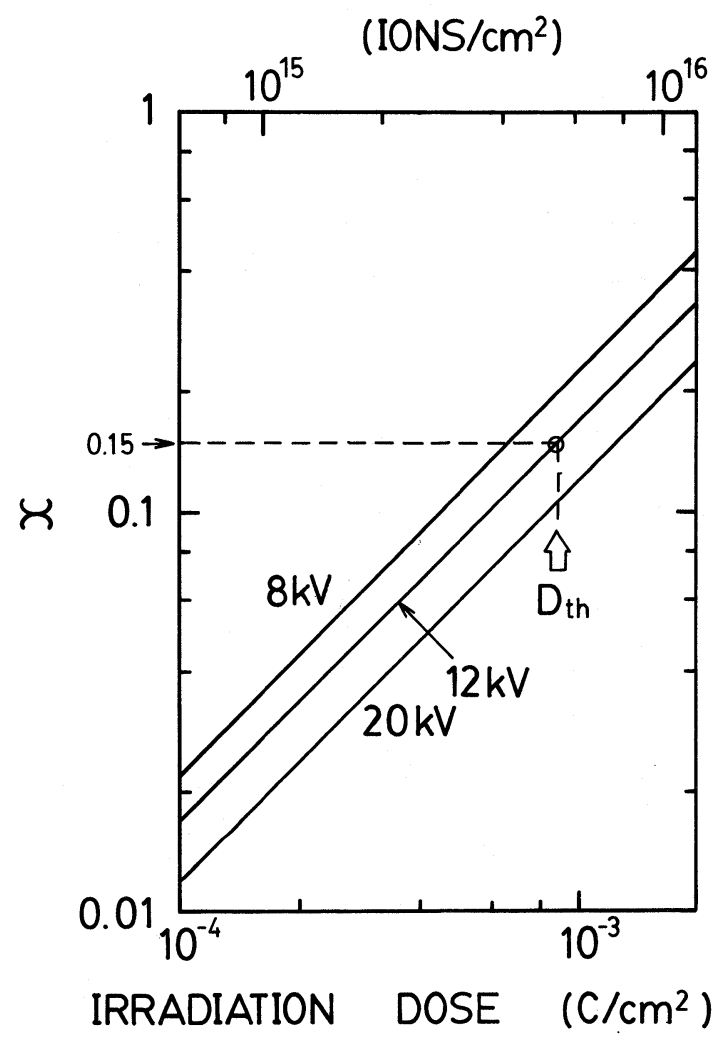

(b)

Fig. 5 (a) Concentration profile for implanted ions in a-MoO 3 film. (b) The dose dependence of stoichiometric parameter $x$ of sodium molybdenum bronze at the surface.

ないことを考慮すると，イオン照射部分の比抵抗はイオ ン照射前 $\left(1.6 \times 10^{8}[\Omega / \square] \times 1.5 \times 10^{-5}[\mathrm{~cm}]=2.4 \times 10^{3}\right.$ $\Omega \mathrm{cm})$ に比べて 6 桁程度変化しているとみられる.

\section{3 レジスト効果の機構}

$\mathrm{a}-\mathrm{MoO}_{3}$ 薄膜に $\mathrm{Na}^{+}$ビームを照射することにより上記 のような化学的, 電気的性質が变化する機構として, ナ トリウムモリブデンブロンズ $\mathrm{Na}_{x} \mathrm{MoO}_{3}$ の形成が考えら れる。一般に, 遷移金属酸化物である $\mathrm{MoO}_{3}, \mathrm{WO}_{3}$, $\mathrm{ReO}_{3}, \mathrm{TiO}_{2}, \mathrm{~V}_{2} \mathrm{O}_{5}$ などは外部からイオン $\mathrm{M}$ を導入する ことによってブロンズと呼ばれる物質群を形成する。 そ の反応式は $\mathrm{MoO}_{3}$ の場合次の上うになる.

$$
\mathrm{MoO}_{3}+x \mathrm{M}^{+}+x e^{-} \rightleftarrows \mathrm{M}_{x} \mathrm{MoO}_{3}(0<x<1)
$$

但し $\mathrm{M}$ の種類はプロトン, アルカリ金属,アルカリ土 類金属，In， Sn，Ag などである．このとき $\mathrm{M}$ は電気的 にはドナーとして働き, 光学的にはカラーセンター形成 の原因となる。このようなブロンズには以下の様な特徴 がある71.

(1)アルカリ，酸に侵されにくく，化学的に安定.

(2) Mの種類により特有な色を呈し，金属光沢をとも
なう。

(3) $x$ がある值になると絶縁体から金属へ転移をおこ 寸

$\mathrm{a}^{-} \mathrm{MoO}_{3}$ 薄膜が $\mathrm{Na}^{+}$ビーム照射により, $\mathrm{NaOH}$ 水溶液 に対する溶解度の変化を示すのは上記(1)の特徴を裏付け るものである，またイオンドースが増加するにつれ，ペ イルブルーから金属光沢をもつダークブルーへ変化する こと, シート抵抗 $R_{\mathrm{s}}$ が $D_{\mathrm{th}}$ 付近で急減することも， (2)，(3)の性質と矛盾しない.

ここでは(3)の性質との関連を定量的に調べるため, イ オンドースと表面における $x$ 值との関係を計算してみ た. 前述のように, $\mathrm{a}-\mathrm{MoO}_{3}$ 薄膜に入射した $\mathrm{Na}$ の濃度 分布は正規分布で近似でき, Fig. 5(a)の様なプロファ イルが考えられる。図中斜線で示した部分は実際には $\mathrm{a}-\mathrm{MoO}_{3}$ 薄膜の表面層に堆積するものと考えて $\mathrm{a}-\mathrm{MoO}_{3}$ 薄膜表面での $\mathrm{Na}$ の濃度を計算し, $\mathrm{MoO}_{3}$ との組成比 $x$ を求めた。そその結果を Fig. 5(b) と示す. 図から, 加速 電圧 $V=12 \mathrm{kV}$ のとき, 例えば膜厚 $660 \mathrm{~nm} の D_{\mathrm{th}}$ に対 応するドースでは $x=0.15$ となり, $\mathrm{Na}_{x} \mathrm{MoO}_{3}$ が金属的 
挙動を示すとされる $x$ 值 $(0.16)^{8)}$ とほぼ一致する。また 逆に $x=0.16$ に必要なドース $D_{0.16}$ を $V$ に対して求める と, Fig. 2 に点線で示すように実験データと同様な挙動 を示すことがわかった。

以上のことから, $\mathrm{a}^{-} \mathrm{MoO}_{3}$ 薄膜の $\mathrm{Na}^{+}$ビームによる レジスト効果は，イオン注入により生成されたモリブデ ンブロンズ $\mathrm{Na}_{x} \mathrm{MoO}_{3}$ がしきい值ドースで絶縁体一金属 転移を起こすことに伴う化学ポテンシャルの変化の結果 として説明できる。しかし，この他にもイオン衝撃によ る薄膜表面の結晶化や組成変化などの影響も考えられる ので, この機構を裏付けるためには光学吸収スペクト ル, 電子線回折, 表面組成分析などの幅広い測定が必要 である.

$\mathrm{MoO}_{3}$ は $10^{-6} \sim 10^{-5}$ Torr における蒸発温度が489〜 $526^{\circ} \mathrm{C}$ と $\mathrm{WO}_{3}$ のそれ $\left(865 \sim 989^{\circ} \mathrm{C}\right)$ に比べて非常に低 $\left\langle{ }^{9)}\right.$, 容易に膜の形成ができる，また，蒸着したままの 薄膜のアルカリに対する溶解性も高く，プロセス上は $\mathrm{WO}_{3}$ より有利である。 さらに, バンドギャップが 4.5 $\mathrm{eV}^{10)}$ で, $\mathrm{WO}_{3}$ の $2.6 \mathrm{eV}^{11)}$ よりも大きく, 蒸着膜のシー 卜抵抗が高いので, 本実験でも示されたように，イオン 照射による電気的特性の変化を検出するのに都合がよ い. $\mathrm{MoO}_{3}$ の使用によって電気的特性の面からもブロン ズの生成が裏付けられたといえる、ブロンズが金属に転 移する $x$ 值は $\mathrm{Na}_{x} \mathrm{WO}_{3}$ についてはほぼ特定 $(x=0.2$ $0.3)^{12)}$ されている. $\mathrm{Na}_{x} \mathrm{MoO}_{3}$ についての正確な值はま だ不明であるが，前述したように $x=0.16$ ですでに金属 的挙動を示すことがわかっている，イオンの飛程は $\mathrm{a}^{-}$ $\mathrm{MoO}_{3}$ の方が大きいにもかかわらずレジス卜感度が $\mathrm{a}-$ $\mathrm{WO}_{3}$ よりもやや高い(13)のは，xのしきい值の差が強く影 響しているためと思われる.

無機アモルファス薄膜のレジスト効果はイオン照射に よるドーピング効果または構造変化に基づいている.こ のことは分子鎖の切断・架橋という高加速電圧領域にお ける電子的励起を基本としたポリマーレジストの機構と 対照をなす. 分子間相互作用が強く, 励起状態の様々な 緩和過程が存在するポリマーにおいては，イオンドース の増大に対してエッチング特性の変化が急激には起こり にくい，このため， $\gamma$ 值が小さく，解像度が大きな制約 をうける。これに対して無機レジストでは，上述のよう な一種の相転移ともいうべき現象がレジスト効果の基本 となっている，したがって， $D_{\mathrm{th}}$ 付近でのドースのわず かな変化に対してエッチング特性が鋭く変化し， $\gamma$ 值は きわめて大きくなる．このような強い非直線性は高解像 度リソグラフィを実現するのに非常に有利である。ま た, 膜厚を任意に設定できることや膨潤の問題がないこ
とも無機レジストの利点といえよう.

\section{4. むすび}

$\mathrm{a}-\mathrm{MoO}_{3}$ 薄膜は比較的低エネルギーのイオン照射によ り, $\mathrm{a}-\mathrm{WO}_{3}$ 薄膜と同様, 高コントラストのネガ形レジ スト効果を示すことがわかった. イオン照射後の化学 的, 電気的性質の変化は $\mathrm{Na}_{x} \mathrm{MoO}_{3}$ の生成に基づくもの と考えられる。特にシート抵抗の著しい減少は, $\mathrm{a}^{-}$ $\mathrm{MoO}_{3}$ 薄膜が単に無機レジストとして機能するだけでな く,メタライゼーションへの応用の可能性ももっている ことを示す、今後はレジストとしての特性を実用的な観 点から検討するため, より高い加速電圧による解像度の 評価，イオンビームミキシングによる感度の向上, ドラ イエッチングへの適用なども試みていく、また，イオン 種に実用的なプロトンなどを用いて実験を行う。さら に, $\mathrm{WO}_{3}, \mathrm{MoO}_{3}$ と同様にブロンズを生成すると思われ る $\mathrm{ReO}_{3}, \mathrm{TiO}_{2}, \mathrm{~V}_{2} \mathrm{O}_{5}$ なども含め, 系統的な実験および 改質効果の機構の検討を行う予定である.

終りに, ご援助いただいた本学, 木内雄二教授, なら びに日頃ご指導いただく東北大学名誉教授吉田重知先生 に深く感謝申し上げる.

\section{〔文献〕}

1) D. B. Rensch, J. Y. Chen, W. M. Clark, Jr. and M. D. Courtney: J. Vac. Sci. Technol. B, 3 (1985) 286.

2）越田信義・富田 修：真空, 27 (1984) 596.

3) N. Koshida and O. Tomita: Jpn. J. Appl. Phys. 24 (1985) 92.

4) T. M. Hall, A. Wagner and L. F. Thompson: J. Appl. Phys. 53 (1982) 3997.

5) J. Lindhard, M. Scharff and H. E. Schiott: Mat. Fys. Medd. Dan. Vid. Selsk. 33 (1963) 14.

6) G. Dearnaley, J. H. Freeman, R. S. Nelson and J. Stephen: Ion Implantation (North-Holland, Amsterdam, 1973) 766 .

7）可知祐次，小菅皓二:「非化学量論的金属化合物」 (丸善, 1975) 59 .

8) A. Wold, W. Kunnmann, R. J. Arnott and A. Ferretti: Inorg. Chem. 3 (1964) 545.

9）「薄膜ハンドブック」学振薄膜第131委員会編（オ 一ム社, 1983) 917.

10) S. K. Deb and J. A. Chopoorian: J. Appl. Phys. 37 (1966) 4818.

11) G. Hoppmann and E. Salje: Phys. Status solidi (a) 37 (1976) K187.

12) P. A. Lightsey, D. A. Lilienfeld and D. F. Holcomb: Phys. Rev. B 14 (1976) 4730.

13) N. Koshida, O. Tomita and Y. Iketsu: Ext. Abstracts of the 17th Conf. on Solid State Devices and Materials, Tokyo, 1985, pp. 369-372. 